\title{
In-Situ Measurements in Overconsolidated Clay
}

\author{
Eszter Horvath-Kalman ${ }^{1}$ \\ ${ }^{1}$ Institute of Civil Engineering, Szent István University, Budapest, Hungary \\ kalman.eszter@ybl.szie.hu
}

\begin{abstract}
The study is about the general genesis process of overconsolidated soils, as well as the effects of the overconsolidated ratio to structures. It will demonstrate the possible methods for the determination of the values of overconsolidated ratio and of earth pressure at rest and of the other soilphysical parameters; further, the processing of measurement results, through which the values of OCR (Overconsolidated ratio) and of $\lambda 0$ (Earth pressure at rest) and of c, E soil-physical parameters (friction angles, cohesion and Young modulus) in the Kiscelli Clay Marl have been determined by Selfboring Pressuremeter.
\end{abstract}

Keywords: In-situ measurement, Selfboring Pressuremeter, soil-physical parameters, overconsolidated clay

\section{INTRODUCTION}

Downtown areas of large cities are reaching the limit of their capacities therefore utilization of underground space is becoming more and more necessary. The under constructions were growing parallelly to fast expansion of large cities in the previous century, the growth-rate of which is further increasing these days. Excavation and construction in underground spaces is supposed to be handled together with wider and wider exploration of soils and rock layers. By the building in of deeper and deeper soil layers overconsolidated soil or rock strata are discovered. The behaviour of overconsolidated soils is thoroughly explored and investigated. The significant horizontal stresses emerging in overconsolidated soil- and rock-strata give rise to high horizontal loads to structures.

In this study of the investigations the objective was to determine the natural horizontal and vertical stresses at rest in overconsolidated clay layer. [12]

The stress condition at rest means a stress space of natural stress conditions free from human intervention. There are conditions used by both the soil- and rock-mechanics for the sake of simplification. These are for instance homogeneity, isotropicity and the elasticity of rock masses. The primary stress condition - which is practically identical with the stress condition at rest - is the result of the dead-weight loads of soil- or rock mass but it can be changed by tectonic activities, desiccation or other physical influences. The determination of the coefficient of the earth pressure at rest differs significantly in the area of the classical soil-mechanics and in that of the classical rock-mechanics. [6, 14]

In cases where the metamorphosis of soils to rock has already started although the process has not yet been completed the rules of classical soil mechanics cannot be applied however the rules of classical rock mechanics are not applicable either. They are in a transitory condition implying its own special rules and behaviours. 
Laboratory tests are basically used for rocks and for soils taken in general soil models are used for soils while rock models are used for rock masses. Consequently these models are not aimed for transitory rocks but with the approximate results to be handled with reservation. It is possible to determine the value of preliminary loading with the use of oedometer tests in the course of laboratory investigations and in-situ tests on the site although it is not possible to establish further soil- or rock-mechanical properties of an overconsolidated layer. $[8,10,11]$

The optimum method to determine vertical and horizontal stresses is the use of local, in-situ investigations since these measurements have the least disturbing effects on the original stress conditions of a soil layer under test.

Four different in-site investigations (see Figure 1) have been performed in order to determine the overconsolidated ratio, the earth pressure at rest and other soil-physical parameters: measurement with an earth-pressure cell; measurement with a borehole cell; and measurement with selfboring pressuremeter. Therefore these three solutions are preferred not including indirect determination.

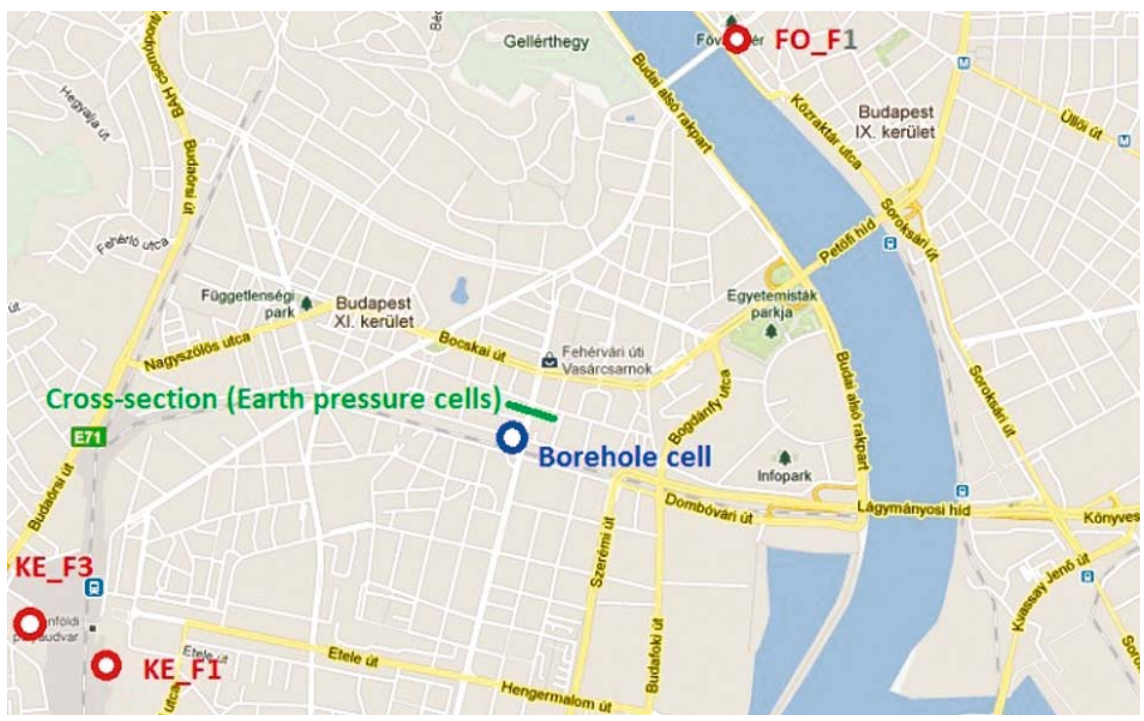

Figure 1. Measurement points (Selfboring Pressuremeter: FO_F1, KE_ F1, KE_F3; Borehole cells and Earth pressure cells)

However it must be taken into consideration that these measuring applications including earth pressure cells and borehole cells can be used only once and are bound to the measuring point since these are permanently installed: subsequently to the instruments having been installed there is no way to change, to recover or to reuse them. This problem does not occur in the case of measurements with self-boring pressuremeters; here the tests can be repeated or analyzed any times. In many cases higher efficiency and wider range can be achieved in the investigation of soil layers where we can determine the normal and special soil-physical parameters such as Overconsolidation ratio or horizontal earth pressure value by using more widespread soil-mechanical investigations.

In the course of our research project we compared the results of widespread soil-mechanical tests of an overconsolidated clay layer performed both in-situ and in a laboratory with the test results obtained by using borehole cells and a selfboring pressuremeter. 


\section{ON-SITE INVESTIGATIONS APPLIED}

\subsection{Earth pressure cell}

The research was launched by earth pressure cells installed around a tunnel section built with NATM (New Austrian Tunneling Method) in the course of the constructions of the underground (metro). [13] The measurement results are shown on Figure 2 where R refers to radial cells, $\mathrm{T}$ refers to tangential cells and the results are measured in kilopascal. The tunnel is running 15 meters under the surface in weathered soil layers.

During the investigation both tangential and radial cells have been installed. These cells determined the value of normal force emerging in the shotcrete wall as well as the value of the force exercised by the rock environment to the shotcrete wall.

The measurement results outlined that the value of vertical and horizontal stresses around the completed tunnel are almost identical. We can also conclude from this that the soil layer may as well be overconsolidated. [3]

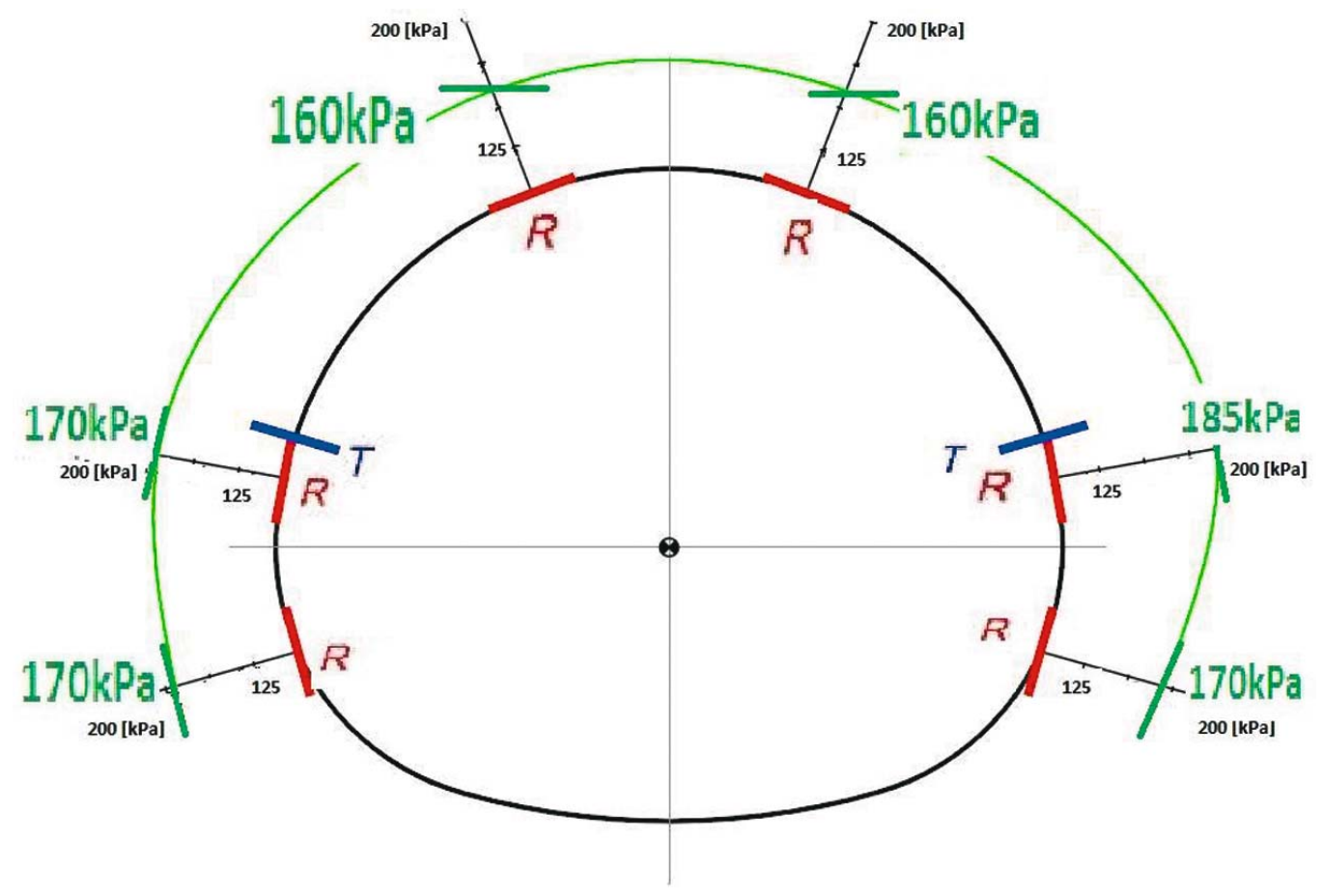

Figure 2. Points at which the earth pressure cells are located indicating their values.

\subsection{Borehole cell}

Subsequently to processing the results of the measures with earth pressure cell a borehole cell (see Figure 3) was installed in the course investigations. 


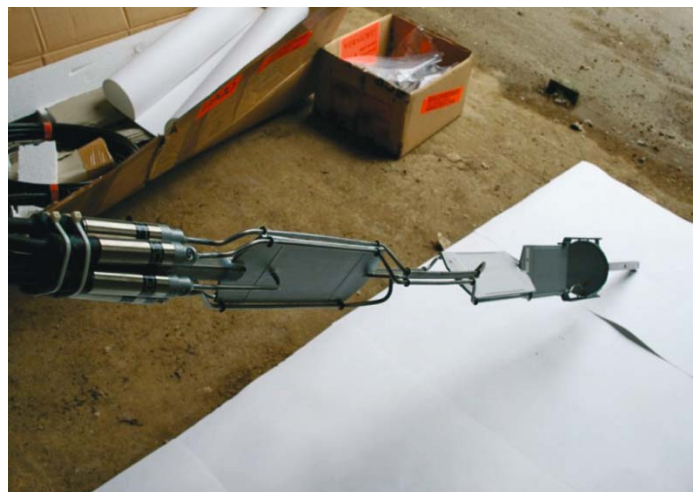

Figure 3. Borehole cell (Glötzl Ltd).

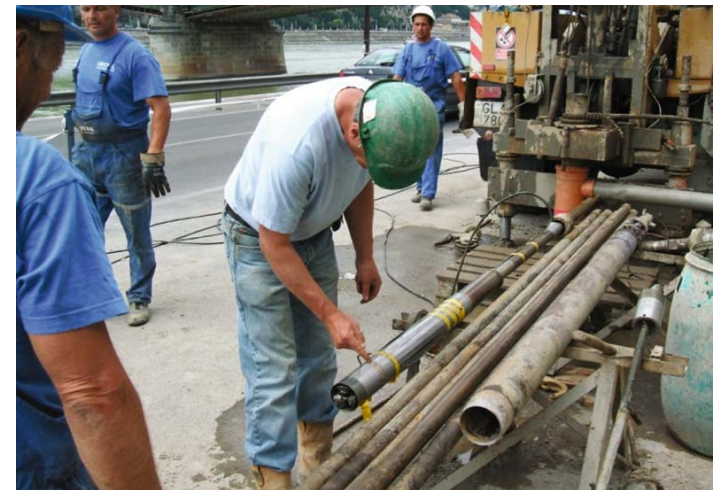

Figure 4. Selfboring pressuremeter

The borehole cell means a system of individual cells always compiled in accordance with individual needs. The system used here is made up of five cells. The cell system is to be installed into a borehole.

The purpose of the investigation was to determine the value of vertical and horizontal stresses in the overconsolidated clay.

The borehole cell was installed in a stress-free area in a depth of 15 meters. The installation depth was selected with regard to the RQD indices. The instrument was installed in the zone of the intact rock environment.

\subsection{Selfboring pressuremeter (SBP)}

In the course of the research it was a great opportunity that we could take part in investigations carried out with selfboring pressuremeter at several locations in the city. The investigations were targeted at defining the overconsolidated ratio of the overconsolidated clay.

Since the measurement results could be used for scientific purposes as well the research group had the opportunity to investigate the Kiscelli Clay at various sites. [2]

In the case of a selfboring pressuremeter the rock environment cannot expand after the borehole had been completed as it is continuously supported until the completion of the investigation process. This device allows us to determine the in-situ stresses in any cases.

SBP is a special device combining the tooling required for boring and the pressuremeter instrument (see Figure 4).

With the use of the horizontal stress instrument the research group was able to measure the total horizontal stress. In the presence of groundwater or strata-water this device does not measure the total horizontal stress accumulated in the layer but the horizontal stress of the layer and the stress of the water in the layer. In order to enable the device to measure the effective stress of the soil/rock layer two cells are also installed outside the membrane to measure the pore-water pressure, the purpose of which is to determine the value of the neutral stress due to water pressure in the layer. If the total horizontal pressure and the neutral stress are known the effective horizontal stress can be determined. [1] 


\section{MEASUREMENT RESULTS}

In the course of the investigations in-situ measurements have been carried out since 2005 to establish the shear strength, limit pressure and the overconsolidation ratio of the overconsolidated clay caused by a preliminary loading and the value of the resulting horizontal stress. [5]

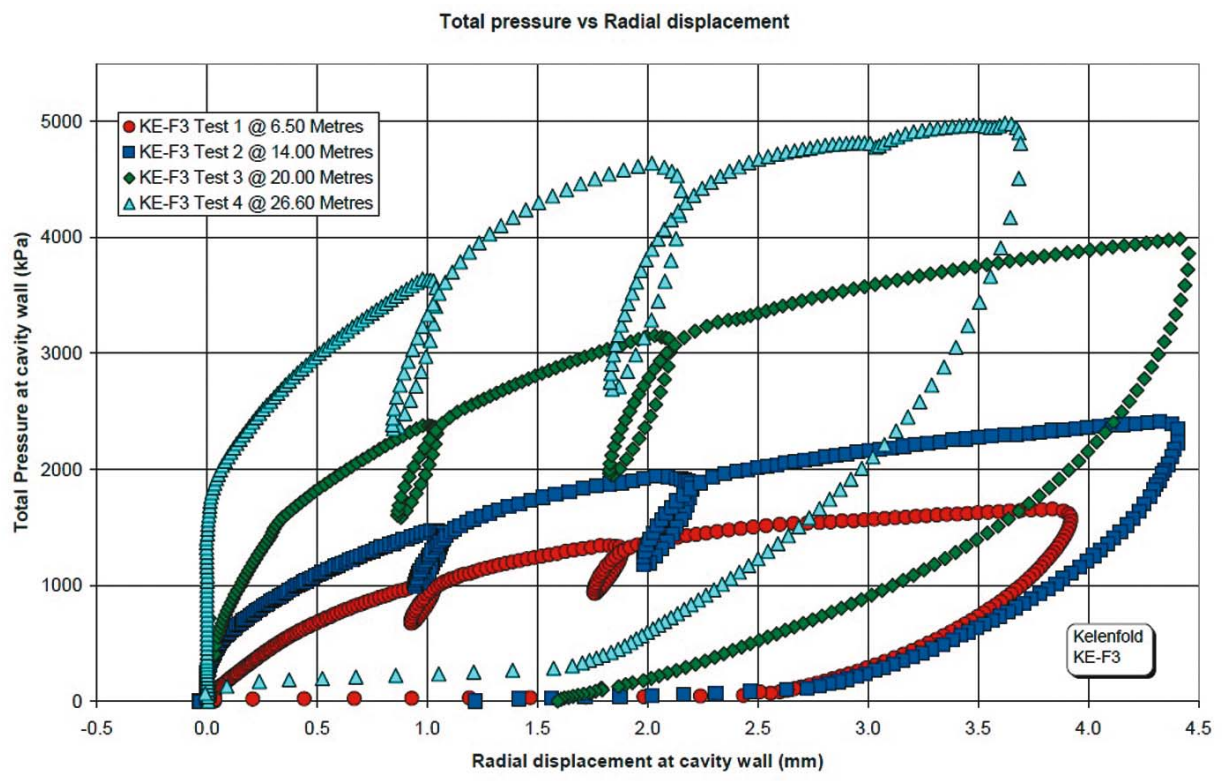

Figure 5. Loading curve (total pressure vs radial displacement) by Selfboring pressuremeter

From the results of the measurement we calculated the yield stress, undrained strength, peak angle of internal friction, the limit pressure and the pressure modulus. The total yield stress $\left(\mathrm{P}_{\text {yield }}\right)$ identified from the initial part of the loading curve where significant curvature is first observed. (see Figure 5) The undrainded strength was defined from a plot of the natural log of the current shear strain versus total pressure. The peak angle of internal friction is derived from undrained tests using a relationship suggested by Worth (1982), based on the ratio of the shear strength to the effective lateral stress. For undrained tests the limit pressure is total limit pressure obtained by extrapolating a plot of total pressure versus log shear strain. [4]

$\begin{array}{ccccccc}\text { Test } & \begin{array}{c}\text { Depth } \\ (\mathrm{mBGL})\end{array} & \begin{array}{c}\mathbf{P}_{\text {yield }} \\ (\mathrm{kPa})\end{array} & \begin{array}{c}\mathbf{c}_{\mathbf{u}} \\ (\mathrm{kPa})\end{array} & \begin{array}{c}\boldsymbol{\phi}^{\prime} \\ (.)\end{array} & \begin{array}{c}\mathrm{P}_{\text {limit }} \\ (\mathrm{kPa})\end{array} & \text { OCR } \\ \text { KE-F1 Test 1 } & 6.50 & 578.1 & 274.7 & 39.8 & 2032 & 12 \\ \text { KE-F1 Test 2 } & 14.00 & 1111.5 & 394.6 & 31.1 & 3158 & 9 \\ \text { KE-F1 Test 3 } & 20.00 & 1388.0 & 558.8 & 27.9 & 4395 & 10 \\ \text { KE-F1 Test 4 } & 26.00 & 1698.8 & 936.7 & 33.6 & 6884 & 16 \\ \text { KE-F3 Test 1 } & 6.50 & 493.5 & 297.7 & 39.3 & 2259 & 13 \\ \text { KE-F3 Test 2 } & 14.00 & 806.3 & 450.4 & 46.9 & 3189 & 10 \\ \text { KE-F3 Test 3 } & 20.00 & 1309.0 & 692.0 & 30.5 & 5123 & 13 \\ \text { KE-F3 Test 4 } & 26.60 & 1976.2 & 926.3 & 31.2 & 6860 & 15\end{array}$

Table 1. Shear strength, limit pressure and overconsolidated ratio 
The total yield stress, the undrainded strength and the limit pressure are increasing by depth. The minimum and the maximum of the determined peak angle of internal friction are between $27.9^{\circ}$ and $46.9^{\circ}$. (see Table 1)

\begin{tabular}{|c|c|c|c|c|c|c|c|c|}
\hline Test & (mBGL) & Loop & $(\mathrm{MPa})$ & $(\mathrm{MPa})$ & $\beta$ & $\begin{array}{c}\text { Gs } \\
\gamma=10^{-4} \\
(\mathrm{MPa})\end{array}$ & $\begin{array}{c}\text { Gs } \\
\gamma=10^{-3} \\
(\mathrm{MPa})\end{array}$ & $\begin{array}{c}\text { Gs } \\
\gamma=10^{-2} \\
(\mathrm{MPa})\end{array}$ \\
\hline \multirow[t]{2}{*}{ KE-F1 Test 1} & 6.5 & 1 & 55.4 & 5.736 & 0.681 & 108.3 & 52.0 & 24.9 \\
\hline & & 2 & 53.1 & 5.575 & 0.640 & 153.5 & 67.0 & 29.3 \\
\hline \multirow[t]{2}{*}{ KE-F1 Test 2} & 14.0 & 1 & 79.5 & 6.861 & 0.611 & 246.8 & 100.8 & 41.2 \\
\hline & & 2 & 73.8 & 6.088 & 0.582 & 286.1 & 109.3 & 41.7 \\
\hline \multirow[t]{2}{*}{ KE-F1 Test 3} & 20.0 & 1 & 80.1 & 9.571 & 0.636 & 273.5 & 118.3 & 51.2 \\
\hline & & 2 & 76.8 & 9.196 & 0.614 & 321.8 & 132.3 & 54.4 \\
\hline \multirow[t]{2}{*}{ KE-F1 Test 4} & 26.0 & 1 & 125.9 & 14.940 & 0.651 & 371.8 & 166.5 & 74.5 \\
\hline & & 2 & 125.6 & 13.099 & 0.610 & 475.6 & 193.7 & 78.9 \\
\hline \multirow[t]{2}{*}{ KE-F3 Test 1} & 6.5 & 1 & 62.9 & 5.978 & 0.639 & 166.2 & 72.4 & 31.5 \\
\hline & & 2 & 64.1 & 4.919 & 0.601 & 194.0 & 77.4 & 30.9 \\
\hline \multirow[t]{2}{*}{ KE-F3 Test 2} & 14.0 & 1 & 71.1 & 9.986 & 0.687 & 178.4 & 86.8 & 42.2 \\
\hline & & 2 & 67.3 & 6.704 & 0.604 & 257.2 & 103.4 & 41.5 \\
\hline \multirow[t]{2}{*}{ KE-F3 Test 3} & 20.0 & 1 & 94.7 & 11.034 & 0.642 & 298.4 & 130.8 & 57.4 \\
\hline & & 2 & 86.5 & 12.560 & 0.649 & 318.4 & 141.9 & 63.2 \\
\hline \multirow[t]{2}{*}{ KE-F3 Test 4} & 26.6 & 1 & 123.6 & 15.227 & 0.645 & 400.5 & 176.9 & 78.1 \\
\hline & & 2 & 111.0 & 12.802 & 0.600 & 509.7 & 202.9 & 80.8 \\
\hline
\end{tabular}

Table 2. Secant shear modulus parameters form unload/reload cycles

During the measurements the pressuremeter modulus $\left(\mathrm{G}_{\mathrm{p}}\right)$ was determined. (Table 2) The pressuremeter modulus is the value obtained by taken the slope of the chord bisecting a cycle of unloading and reloading. (see Figure 5) This will only be secant shear modulus $\mathrm{G}_{\mathrm{s}}$ if the material response is simple elastic. The column $\left(\gamma=10^{-4}\right)$ and the next two quote shear modulus at three magnitudes of shear strain. The equation is $\mathrm{G}_{\mathrm{s}}=\alpha \gamma \beta-1$, where $\mathrm{G}_{\mathrm{s}}$ is secant shear modulus. The non-linear elastic convension from secant shear modulus $\mathrm{G}_{\mathrm{s}}$ to Young's modulus $(\mathrm{E})$ is given by Equation 1 .

$$
E=2 \times \alpha \times(1+v) \times(\sqrt{3 \gamma})^{\beta-1}
$$

Shear modulus is independent of Poisson's ration (v), so converting G parameters to E requires the $v$ be supplied or estimated $v$ in 0,5 for undrained conditions. $\gamma$ is axial strain.

With the investigations performed to determine the overconsolidated ratio and the soilphysical parameters of overconsolidated clay the research group established that the Kiscelli Clay, after its settling down, consolidated under the effect of a nearly 400 meter thick covering layer, and developed to its currently known condition. We were carrying out measurements by the installation of a borehole cell for more than two years in order to ascertain the overconsolidated ratio. Subsequently we processed the results of the measurements with selfboring pressuremeter to determine the OCR value (see Figure 6). [7] 


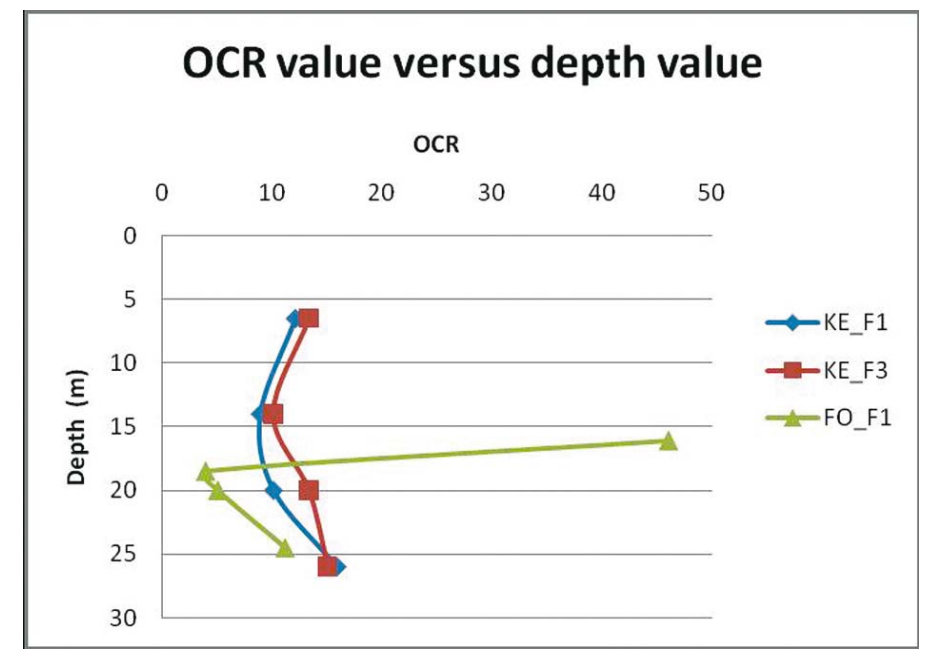

Figure 6. OCR value versus depth value

The Kiscelli Clay Marl is heavily overconsolidated: its overconsolidation ratio varies between 10 and 16 depending on depth. The Figure 6 shows the measurement of FO_F1 which was on the Fovam Square. In the area of the Fovam Square is a mixed zone of the soil, Kiscelli Clay and Tardi Clay under the surface, so the values of the SBP were different than the values of the measurement were in the clean Kiscelli Clay.

To ascertain the horizontal stress at rest the group used the results of the series of measurements of more than two years with the borehole cell as well as those of the selfboring pressuremeter investigations. It was established that the values of the horizontal stress at rest were varying along an ellipse, and the maximum value of the stress in the intact rock mass zone of Kiscelli Clay is $462 \mathrm{kPa}$. [9]

By the result of the measurements of the selfboring pressuremeter we established that the value of the horizontal stress at rest varied between 270 and $1100 \mathrm{kPa}$ depending on depth (see Figure 7).

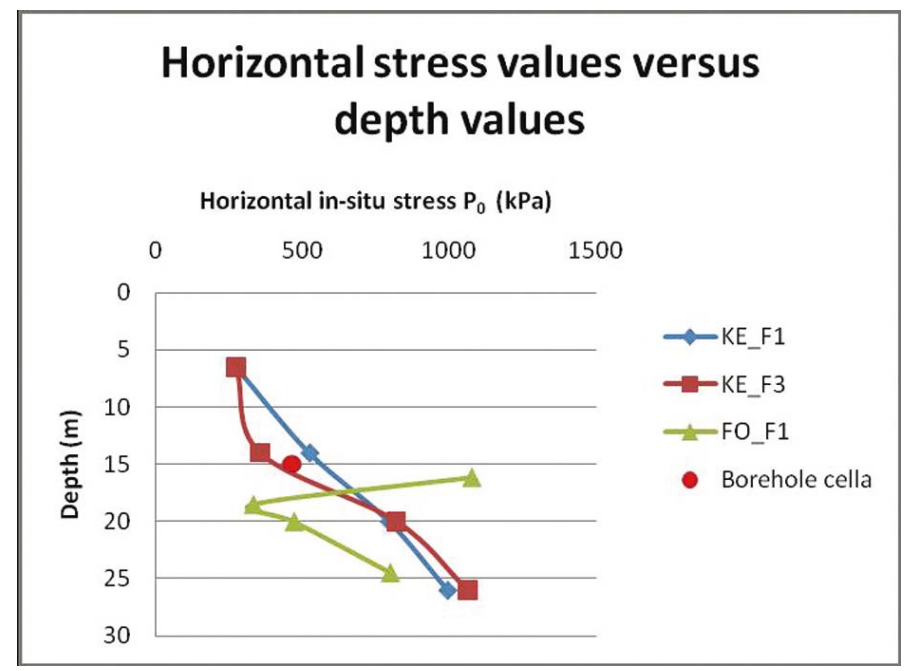

Figure 7. Horizontal stress values versus depth values 
In order to determine the value of the coefficient of the earth pressure at rest we used the measurement results provided by the borehole cell and by the selfboring pressuremeter investigations. The value of the coefficient of the earth pressure at rest in Kiscelli Clay varies between 1.2 and 2.5 in the function of depth (see Figure 8).

As it can be seen on Figure 1 the FO_F1 measurement location was not appointed in the perfect Kiscelli clay (it is more sandy and transition towards the Tardi clay) consequently the measurement results cannot exactly concur with the results measured at points KE_F1, KE_F3 which were measured in the perfect Kiscelli clay.

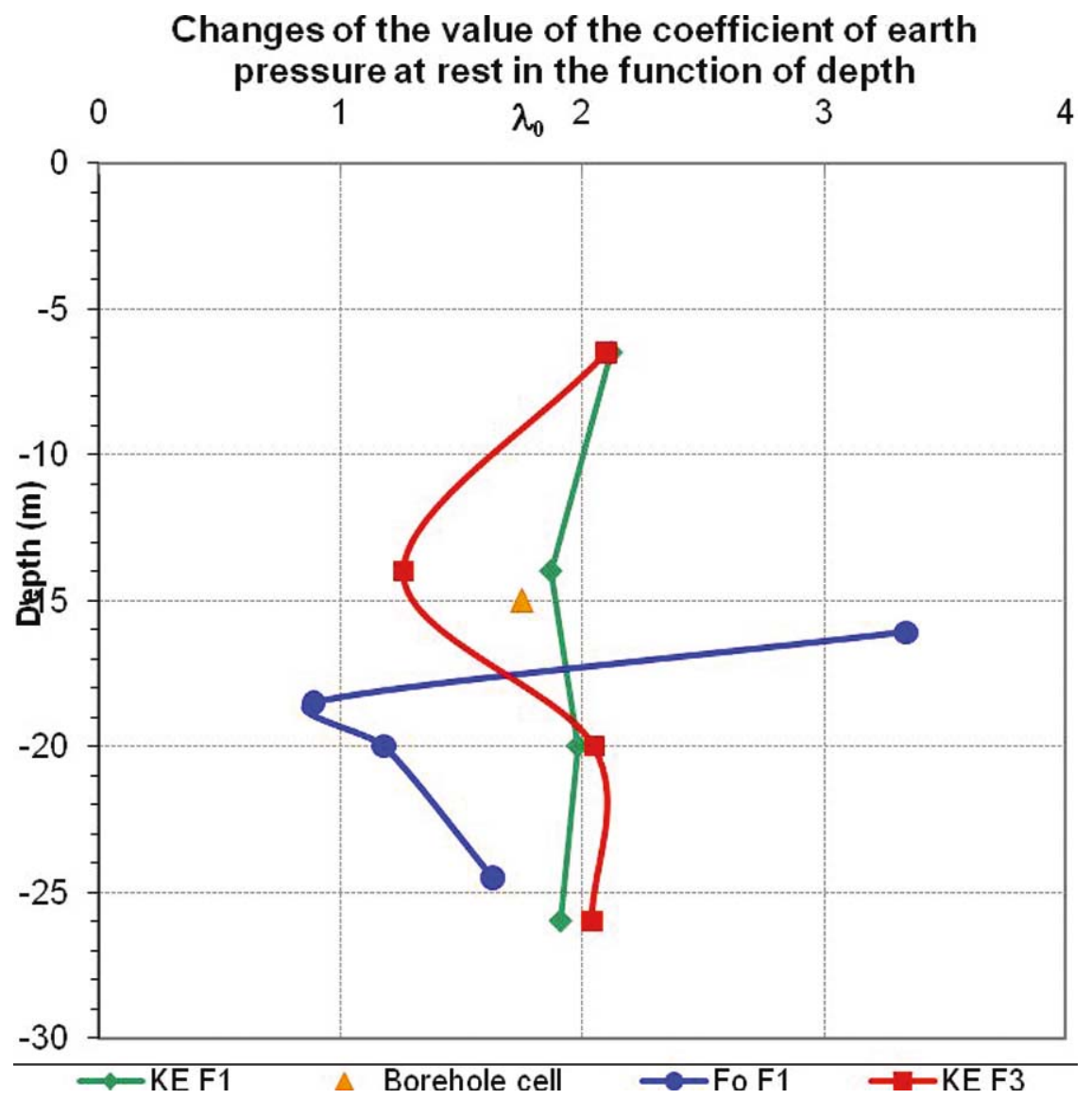

Figure 8. Changes of the value of the coefficient of earth pressure at rest in the function of depth

In normalized form the degree of preconsolidation is termed the overconsolidation ratio (Equation 2)

$$
O C R=\frac{\mathrm{s}_{p}^{\prime}}{\mathrm{s}_{v 0}^{\prime}}
$$

where $\sigma_{\mathrm{v}} 0$ ' is the effective vertical geostatic stress. 


\section{CONCLUSION}

As a result of our investigations it could be established that the method applied by classical soil mechanics and classical rock mechanics for the determination of the value of earth pressure at rest cannot be applied in the case of overconsolidated soils. Our conclusions include that not even approaching calculations established with the application of the rules of classical soil mechanics or classical rock mechanics are recommended in those cases where the stress values at rest for an overconsolidated soil must be determined.

The most accurate results for the determination of primary stresses are those provided by on-site investigations. From among the scale of in-site investigations the measurements recommended are those where the rock environment to be tested cannot expand.

The values of the horizontal stress, the coefficient of the earth pressure at rest $\left(\lambda_{0}\right)$ and the OCR could be measured however in certain cases this information is not enough since the direction of the measurements is indispensable.

In the course of the research work we demonstrated that the Kiscelli Clay is heavily overconsolidated and consequently the value of the horizontal stress is 1.5 to 2 times higher than the value of the vertical stress.

In general, Overconsolidation ratio decreased due to depth, depended on the determination method.

As a result of the series of investigations, it can be established that in the case of overconsolidated soils the appropriate number of tests must be performed in order to determine layer properties as accurately as possible.

\section{REFERENCES}

[1] Clarke B. G., Pressuremeters in Geotechnical Design. Glasgow: Department of Civil Engineering, University of Newcastle upon Tyne, Blackie Academic \& Professional, an imprint of Chapman \&Hall, 1995

[2] Horvath T., Expert opinion on the geotechnical, engineering geological and hydrogeological issues regarding the Kelenföld Junction Station, Budapest, 221pp., 2005

[3] Horvath T., Expert opinion on the geotechnical, engineering geological and hydrogeological issues regarding the Bocskai Street Station, Budapest, 215 pp., 2005

[4] Horvath T., Cambridge Insitu Ltd., Budapest Metro Line 4 Kelenfold Junction station \& reversing facility addition site investigation: Text report Volume 1 and 2, Budapest, 2008

[5] Hudson J. A., Stresses in rock masses; Processings of Eurock Conference, Dubrovnik, 2009

[6] Jaky J., Talajmechanika, Budapest:Egyetemi Nyomda. 143pp., 1944

[7] Jaky J., New theory of earth pressure. 2 nd ICSMFE, Rotterdam, 1948

[8] Jozsa V., Empirical correlations of overconsolidation ratio, coefficient of earth pressure at rest and undrained strength: 2 CJRCE - Second Conference of Junior Researchers in Civil Engineering, Budapest Hungary, pp.88-92., 2013

[9] Kalman H. E., In situ measurments in overconsolidated clay: Earth pressure at rest, Periodica Polytechnica Civil Engineering, 56/2 (2012) 239-244 DOI: 10.3311/pp.ci.2012-2.10, 2012

[10] Lunne T., Robertson P.K. and Powell J.J.M., Cone Penetration Testing in Geotechnical Practice, Taylor \& Francis, London, pp. 60-61., 2002

[11] Mahler A. \& Szendefy J., Estimation of CPT resistance based on DPH results. Periodica Polytechnica Civil Engineering, 53/2 (2009) 101-106 DOI: 10.3311/pp.ci.2009-2.06, 2009

[12] Schaid F., In Situ Testing in Geomechanics, Taylor \& Francis Group, London 2009

[13] Szechy K., The art of Tunnelling, Budapest:Tankönyvkiadó, 1961

[14] Terzaghi V. K., Theoretical Soil Mechanics, John Wiley and Sons, Inc., New York, 1943 